\title{
Presence of viral haemorrhagic septicaemia virus (VHSV) in the environment of virus-contaminated fish farms and processing plants
}

\author{
Pia Vennerström ${ }^{1, *}$, Leena Maunula ${ }^{2}$, Elina Välimäki ${ }^{1}$, Anna-Maija Virtala ${ }^{3}$ \\ ${ }^{1}$ Veterinary Bacteriology and Pathology Research Unit, Finnish Food Authority, 00027 Finnish Food Authority, Finland \\ ${ }^{2}$ Department of Food Hygiene and Environmental Health, Faculty of Veterinary Medicine, 00014 University of Helsinki, Finland \\ ${ }^{3}$ Department of Veterinary Biosciences, Faculty of Veterinary Medicine, University of Helsinki, 00014 University of Helsinki, Finland
}

\begin{abstract}
After the first outbreak of viral haemorrhagic septicaemia virus (VHSV) in Finnish brackish water rainbow trout Oncorhynchus mykiss farms, infection spread rapidly between the farms. The infrastructure of fish farming did not take into account spreading of infectious fish diseases. To show the presence of VHSV in the environment, we tested seawater, sediment and wild blue mussels Mytilus edulis from VHSV-infected fish farms, and liquid waste from a processing plant that handled infected rainbow trout. Additionally, blue mussels were bath-challenged with VHSV (exposed to cultivated virus or naturally infected rainbow trout). To detect VHSV, virus isolation in cell culture and real-time reverse transcriptase polymerase chain reaction (qRT-PCR) were used. The virus or viral RNA was detected in sea water and in liquid waste from processing plants during wintertime when water temperature is close to $0^{\circ} \mathrm{C}$ and sunlight is sparse. VHSV did not appear to replicate in blue mussels in our study. Therefore, blue mussels were not considered relevant carriers of VHSV. However, traces of viral RNA were detected up to $29 \mathrm{~d}$ post challenge in mussels. Contact with water from processing plants handling VHSV-infected fish populations increases the risk of the disease spreading to susceptible fish populations, especially during cold and dark times of the year.
\end{abstract}

KEY WORDS: Viral haemorrhagic septicaemia virus · Environment $\cdot$ Sea water $\cdot$ Liquid waste Blue mussels $\cdot$ Processing plant · UV-light

\section{INTRODUCTION}

In 2000, in the Province of Åland, Baltic Sea, Finland, several brackish water fish farms producing rainbow trout Oncorhynchus mykiss for consumption were infected by viral haemorrhagic septicaemia virus genotype Id (VHSV Id) (Raja-Halli et al. 2006). The virus spread rapidly to almost all fish farms, resulting in the entire province being declared a restriction area in 2001 (Raja-Halli et al. 2006).

VHSV belongs to the genus Novirhabdovirus of the family Rhabdoviridae (Walker et al. 2000). It is a single-stranded enveloped RNA virus that is catego-

*Corresponding author: pia.vennerstrom@ruokavirasto.fi rized into 4 genotypes (I-IV), of which I and IV have several sublineages (Ia-Ie, IVa-IVc) (Snow et al. 1999, Einer-Jensen et al. 2005, Elsayed et al. 2006, Ammayappan \& Vakharia 2009, Pierce \& Stepien 2012). VHSV is shed in the water via fish urine and reproductive fluids, and virus has been shown in subclinical and clinically affected rainbow trout as well as survivors of the disease (Wolf 1988, Oidtmann et al. 2011). VHSV-positive fish farms and liquid waste from processing plants handling VHSV-positive fish are considered a risk to susceptible fish species if released into the environment (Hervé-Claude et al. 2008, Bain et al. 2010, VHSV Expert Panel and Work-

(C) The authors 2020. Open Access under Creative Commons by Attribution Licence. Use, distribution and reproduction are unrestricted. Authors and original publication must be credited.

Publisher: Inter-Research · www.int-res.com 
ing Group 2010, Phelps et al. 2012, Pearce et al. 2014, Oidtmann et al. 2018).

Blue mussels Mytilus edulis are common inhabitants of brackish water fish farms in the Baltic Sea. The mussels attach to farm equipment such as anchor ropes and supporting framework where they feed by filtering particles from the water. The seabed beneath the net pens is also covered by mussels that cannot be removed when a fish farm is fallowed due to notifiable fish diseases. The role of shellfish used for consumption as carriers of viral pathogens of human origin such as noroviruses, enteroviruses and hepatitis A virus is well described (Richards 1985, 1988, Power \& Collins 1989, Kingsley \& Richards 2003). The role of mussels as transmitters of fish pathogens is not well known. There are indications that infectious pancreatic necrosis virus (IPNV) and other aquatic birnaviruses may persist in mussel tissue (Mortensen et al. 1992, Rivas et al. 1993). Furthermore, a challenge study showed that blue mussels were able to transfer IPNV to challenged Atlantic smolts (Molloy et al. 2013). IPNV is a nonenveloped birnavirus that is resistant to physicochemical factors (Bovo et al. 2005). On the other hand, infectious salmon anaemia virus (ISAV), which is an enveloped virus like VHSV, did not persist in mussels after the source of infection was removed and thus mussels are not considered as potential transmitters of ISAV (Skår \& Mortensen 2007). In another challenge of blue mussels with ISAV, viral RNA was detected in all samples from the $144 \mathrm{~h}$ challenge, but all samples were negative by culture analysis (Molloy et al. 2014). There are no reports on whether blue mussels could act as transmitters of VHSV or shed the virus. Survival of VHSV outside the host depends on physico-chemical conditions in the environment (Bovo et al. 2005). In cold water $\left(4^{\circ} \mathrm{C}\right)$, VHSV can survive for a few days in natural fresh water or seawater and up to a year in filtered fresh water (Parry \& Dixon 1997, Hawley \& Garver 2008). In warm temperatures $\left(20^{\circ} \mathrm{C}\right)$, VHSV is less stable (Hawley \& Garver 2008). Fresh water seems to be more favourable for virus survival than seawater (Hawley \& Garver 2008). Rhabdoviruses such as VHSV and infectious haematopoietic necrosis virus are sensitive to ultraviolet (UV) irradiation (Øye \& Rimstad 2001, Yoshimizu et al. 2005, Afonso et al. 2012).

Attempts to eradicate VHS from the fish farms in the restriction area in the Province of Åland failed several times (Raja-Halli et al. 2006). VHS-positive fish farms were emptied of fish, and farming equipment was removed, washed and disinfected according to instructions from the authorities. After repopu- lation of fallowed ( $>8 \mathrm{wk}$ ) farms with fish from a VHSV-free area, new infections were detected as early as 2 wk after repopulation (our own observations). In earlier studies performed in this restriction area, we described different surveillance procedures and diagnostic methods to screen for VHSV-infected fish populations (virus isolation in cell culture and real-time reverse transcriptase polymerase chain reaction [qRT-PCR] and serology to detect antibodies against VHSV). We found active surveillance performed by the fish farmers, whenever there were signs of a possible fish disease, to be more effective than passive surveillance. The results of the qRT-PCR method corresponded well with the results from the parallel testing of the same samples with virus isolation in cell culture (Vennerström et al. 2017). We screened wild fish living in the vicinity of VHSVinfected fish farms in this restriction area for VHSV during 4 years, but wild fish were not found to be relevant carriers of this virus (Vennerström et al. 2018). On the other hand, whitefish Coregonus lavaretus that were cultured in the same farms or close to VHSV-infected rainbow trout populations were probable disease transmitters, as they were found to be infected by VHSV without observed mortality in an infection trial (Vennerström et al. 2018).

The infrastructure of fish farming in the study area did not consider spreading of infectious diseases. Processing plants were important to fish farming practices, and contacts between fish farms and processing plants occurred daily. Contacts between infected fish populations were also common during daily servicing of fish farms by personnel and boats. In the present study, we looked for possible reservoirs of the virus in the environment surrounding the fish farms and processing plants, such as wild mussels, sediment, seawater from VHSV-infected farms and liquid waste from plants processing VHSVpositive fish populations. No studies have addressed these issues concerning VHSV genotype Id in brackish water fish farms in a VHSV restriction area, and no studies of the persistence of VHSV in mussels have been reported. To address whether blue mussels could be carriers of VHSV by protecting the virus from environmental factors such as UV light, we tested wild mussels living in VHSV-infected fish farms for VHSV and performed 2 infection trials with mussels in VHSV-contaminated aquarium water.

Information on the source of VHSV in the environment was needed to plan eradication measures and point out to farmers possible sources of infection and the importance in changing the infrastructure to consider infectious fish diseases. 


\section{MATERIALS AND METHODS}

\subsection{Collection of seawater, sediment and liquid waste samples}

In April and May 2008, as well as in January and March 2009, seawater samples were collected from the close vicinity $(<1 \mathrm{~m})$ of net pens in 2 fish farms: Farm A owned by Company 1 and Farm B owned by Company 2. Both companies produced rainbow trout for human consumption in the Baltic Sea on the southwest coast of Finland. The processing plant of Company 1 was situated next to Farm A. The processing plant of Company 2 was situated $>5 \mathrm{~km}$ from Farm B, but whitefish Coregonus lavaretus were farmed next to the processing plant during this study. Both Farms A and $B$ had rainbow trout populations experiencing a clinical VHS outbreak at the time of sampling. Seawater samples were also collected at the loading dock of the fish processing plant of Company 2 at the time VHSV-positive rainbow trout were pro- cessed; however, during sampling in March 2009, only whitefish were processed at this plant. Water temperatures were $4^{\circ} \mathrm{C}$ in April $2008,7-10^{\circ} \mathrm{C}$ in May 2008 and approximately $0^{\circ} \mathrm{C}$ in January and March 2009. Water samples of 51 were collected from the surface and from $2 \mathrm{~m}$ depth. During April and May, altogether 40 samples were collected on 3 occasions. Sediment was collected from the seabed beneath net pens of Farm A with an Ekman grab sampler. Liquid waste was collected in January and March 2009 from different parts of the processing plant of Company 2: the carbon dioxide stunning basin, bleeding basin, kidney remover and liquid waste drain before and after final decontamination treatment. All water samples were protected from sunlight, kept cool during transport and storage, processed and tested in the Department of Food Hygiene and Environmental Health, Faculty of Veterinary Medicine, University of Helsinki. Sampling sites and the number of water, sediment and liquid waste samples collected are shown in Table 1.

Table 1. Results of testing for viral haemorrhagic septicaemia virus (VHSV) in seawater, sediment and liquid waste water from 2 VHSV-positive fish farms (A and B) and a plant that processed VHSV-positive fish. CPE: cytopathic effect; N: number; nd: not done; pos: VHS-positive samples; PP: processing plant of Company 2; qRT-PCR: direct real-time reverse transcriptase polymerase chain reaction; water filtering: water samples were filtered before testing with qRT-PCR

\begin{tabular}{|c|c|c|c|c|c|c|c|c|c|}
\hline \multirow[t]{2}{*}{ Farm } & \multirow{2}{*}{$\begin{array}{l}\text { Sampling } \\
\text { date }\end{array}$} & \multirow{2}{*}{$\begin{array}{l}\text { Water } \\
\text { temp. } \\
\left({ }^{\circ} \mathrm{C}\right)\end{array}$} & \multirow{2}{*}{$\begin{array}{l}\text { Sample } \\
\text { type }\end{array}$} & \multirow{2}{*}{$\begin{array}{l}\text { Sample } \\
\text { origin }\end{array}$} & \multirow{2}{*}{$\begin{array}{l}\text { N samples } \\
\text { (pooled for } \\
\text { qRT-PCR) }\end{array}$} & \multirow{2}{*}{$\begin{array}{l}\text { Water } \\
\text { filtering }\end{array}$} & \multirow{2}{*}{$\begin{array}{c}\text { Virus isolation } \\
\text { N CPE pos / } \\
\text { N samples }\end{array}$} & \multicolumn{2}{|c|}{$\longrightarrow$ qRT-PCR } \\
\hline & & & & & & & & $\begin{array}{l}\text { N pos / N CPE } \\
\text { pos cell culture }\end{array}$ & $\begin{array}{c}\mathrm{N} \text { water samples } \\
\text { pos / N tested }\end{array}$ \\
\hline \multicolumn{10}{|c|}{ Company 1} \\
\hline A & $\begin{array}{c}\text { April-May } \\
2008\end{array}$ & 4 & Seawater & $\begin{array}{l}\text { Net pens with } \\
\text { VHSV-positive trout }\end{array}$ & 21 & Yes & nd & nd & $1 / 21$ \\
\hline A & $\begin{array}{l}\text { April } \\
2008\end{array}$ & 4 & Sediment & $\begin{array}{l}\text { Under net pens } \\
\text { VHSV-positive trout }\end{array}$ & 10 & & nd & nd & $0 / 10$ \\
\hline \multicolumn{10}{|c|}{ Company 2} \\
\hline $\mathrm{B}$ & $\begin{array}{l}\text { May } \\
2008\end{array}$ & 10 & Seawater & $\begin{array}{l}\text { Net pens with } \\
\text { VHSV-positive trout }\end{array}$ & 19 & Yes & nd & nd & $0 / 19$ \\
\hline \multirow[t]{2}{*}{ PP } & $\begin{array}{c}\text { January } \\
2009\end{array}$ & 2 & Seawater & $\begin{array}{l}\text { Net pens with } \\
\text { VHSV-positive trout }\end{array}$ & $3(1)$ & Yes & $0 / 3$ & nd & $1 / 1$ \\
\hline & & & Seawater & $\begin{array}{l}\text { Loading dock of } \\
\text { slaughterhouse }\end{array}$ & $3(1)$ & Yes & $0 / 3$ & nd & $1 / 1$ \\
\hline \multirow[t]{5}{*}{$\mathrm{PP}$} & January & 2 & Liquid waste & Stunning basin & 3 & & $2 / 3$ & $2 / 2$ & $3 / 3$ \\
\hline & 2009 & & Liquid waste & Bleeding basin & 3 & & $1 / 3$ & $1 / 1$ & $3 / 3$ \\
\hline & & & Liquid waste & Kidney remover & 2 & & $2 / 2$ & $2 / 2$ & $2 / 2$ \\
\hline & & & Liquid waste & $\begin{array}{l}\text { Drain before } \\
\text { disinfecting }\end{array}$ & 3 & & $3 / 3$ & $3 / 3$ & $3 / 3$ \\
\hline & & & Liquid waste & $\begin{array}{l}\text { Drain after } \\
\text { disinfecting }\end{array}$ & 3 & & $0 / 3$ & nd & $0 / 3$ \\
\hline $\mathrm{PP}$ & $\begin{array}{c}\text { March } \\
2009\end{array}$ & 0 & Seawater & $\begin{array}{l}\text { Loading dock of } \\
\text { slaughterhouse }\end{array}$ & 2 & Yes & $0 / 2$ & nd & $2 / 2$ \\
\hline \multirow[t]{4}{*}{$\mathrm{PP}$} & March & 0 & Liquid waste & Stunning basin & $2(1)$ & & $1 / 2$ & $1 / 1$ & $1 / 1$ \\
\hline & 2009 & & Liquid waste & Bleeding basin & $2(1)$ & & $2 / 2$ & $2 / 2$ & $0 / 1$ \\
\hline & & & Liquid waste & Kidney remover & $2(1)$ & & $2 / 2$ & $2 / 2$ & $1 / 1$ \\
\hline & & & Liquid waste & $\begin{array}{l}\text { Drain before } \\
\text { disinfecting }\end{array}$ & $2(1)$ & & $0 / 2$ & nd & $0 / 1$ \\
\hline
\end{tabular}




\subsection{Wild blue mussels for virological examination}

Blue mussels living on anchor ropes in Farms A and $B$ and on a third fish farm (control Farm C) were tested for VHSV. The sampling scheme is presented in Table 2. Farm $\mathrm{C}$ also produces rainbow trout for consumption in net pens in the Baltic Sea but is situated outside of the VHS restriction area where VHSV has been screened for since 1995 but never reported. Mussels from control Farm C were tested in May 2007 at a water temperature of $9^{\circ} \mathrm{C}$. Mussels from all farms were transported in a cooled transport box on moist paper to the Finnish Food Safety Authority (Evira, now named the Finnish Food Authority) in Helsinki to be tested for VHSV.

\subsection{Collection of mussels for bath challenge studies}

Mussels (length ca. $3 \mathrm{~cm}$ ) for 2 different bath challenges were collected from the anchor ropes of control Farm $\mathrm{C}$ and transported to the laboratory at Evira (first bath challenge) and to a VHSV-positive fish farm (second bath challenge). From the control farm, mussel samples were also collected for VHSV testing.

\subsubsection{Bath challenge of mussels with VHSV}

Three test aquariums (I, II, III), 21 each, were kept in a refrigerated dark room at $5^{\circ} \mathrm{C}$. Seawater for the aquariums was transported in plastic canisters from control Farm C. Sixty mussels were selected and placed arbitrarily in each aquarium. The aquariums were aerated, and the water was changed daily to imitate the natural water currents on the farm where water is changing continuously. The mussels attached to the surface of the aquarium and started filtering water after a few hours. The bath challenge was started the day after transfer. Just before the challenge started, the water from all 3 aquariums (I-III) was removed, the mussels were rinsed 3 times with seawater, and the aquariums were each filled with 21 of seawater. The rinse was performed to make the environment as free from faeces excreted by the mussels as possible before adding $5 \mathrm{ml}$ of VHSV strain
Fika422, genotype Id (GenBank accession no. AY546615; Einer-Jensen et al. 2004), virus titre $10^{7}$ TCID $_{50}$ in each aquarium. The virus had been cultivated in bluegill fry fibroblast (BF-2) cells (Wolf et al. 1966) growing in Eagle's minimal essential medium (MEM) at $16^{\circ} \mathrm{C}$ until complete destruction of the cell monolayer. The virus-containing medium was added to 2 test aquariums (I and II). Aquarium III was used as a negative control, and $5 \mathrm{ml}$ of sterile MEM were added to this aquarium. The control aquarium was treated and sampled in the same way as the 2 test aquariums. Two different challenge times were used: $6 \mathrm{~h}$ for Aquarium I and $24 \mathrm{~h}$ for Aquarium II. Before the challenge was terminated, 10 live mussels from each treated aquarium were collected to be tested for VHSV. The vitality of the collected mussels was determined by evaluating their ability to filter water and to close their shell when experiencing physical contact. Pieces of hepatopancreas of 5 mussels were sampled and pooled in 9 volumes of MEM (proportion of tissue to MEM 1:10); the pooled samples were used in virological examinations. The aquarium water was replaced at the end of each sampling. The remaining mussels in the aquarium were rinsed 3 times with fresh seawater before the aquarium was refilled with new seawater. Samples were collected arbitrarily at intervals described in Table 3 . All waste water was poured into plastic canisters and treated with Virkon ${ }^{\mathrm{TM}} \mathrm{S}$ according to the manufacturer's instructions before being poured into the disinfection tank that heated waste water to $127^{\circ} \mathrm{C}$ for $60 \mathrm{~min}$. The outer surfaces of the aquariums and other equip-

Table 2. Results of testing for viral haemorrhagic septicaemia virus (VHSV) in the hepatopancreas of wild blue mussels from 2 VHS-positive fish farms (A and B) farming rainbow trout for consumption in the Province of Åland, Finland, and from a similar farm situated in a VHS-free zone on the west coast of continental Finland used as a control farm (C). N: number; nd: not done; qRT-PCR: real time reverse transcriptase polymerase chain reaction

\begin{tabular}{|c|c|c|c|c|c|}
\hline Farm & Sampling date & $\begin{array}{c}\mathrm{N} \\
\text { mussels }\end{array}$ & $\begin{array}{c}\mathrm{N} \\
\text { pools }\end{array}$ & $\begin{array}{c}\text { N pools positive } \\
\text { Cell culture }\end{array}$ & $\begin{array}{l}\text { N pools tested } \\
\text { qRT-PCR }\end{array}$ \\
\hline \multicolumn{6}{|c|}{ Company 1} \\
\hline A & April 2006 & 13 & 7 & $0 / 7$ & nd \\
\hline A & May 2006 & 10 & 10 & $0 / 10$ & $1^{\mathrm{a}} / 10$ \\
\hline A & November 2006 & 100 & 20 & $0 / 20$ & $0 / 20$ \\
\hline \multicolumn{6}{|c|}{ Company 2} \\
\hline B & May 2006 & 10 & 5 & $0 / 5$ & nd \\
\hline B & June 2006 & 50 & 10 & $0 / 10$ & $0 / 10$ \\
\hline \multicolumn{6}{|c|}{ Control farm } \\
\hline $\mathrm{C}$ & May 2007 & 10 & 10 & $0 / 10$ & $0 / 10$ \\
\hline Total & & 193 & 62 & $0 / 62$ & $1^{\mathrm{a}} / 50$ \\
\hline
\end{tabular}


ment used were disinfected with $70 \%$ ethanol, and the surface of the aquarium table and the cool-room floor were treated with Virkon ${ }^{\mathrm{TM}} \mathrm{S}$ every time the water was changed. The aquariums were covered daily with new plastic sheets to avoid cross contamination of the virus between study groups and contamination by disinfectants.
Immediately after the end of exposure, 10 mussels from different parts of each tub were non-randomly collected and sampled. These samples were transported on ice to the laboratory and further processed the next day. The remaining live mussels were transported in a cool box on wet paper to the laboratory where they were placed into 2 aquariums (2 1 each;

\subsubsection{Bath challenge using VHSV-infected rainbow trout}

The second bath challenge was performed at Farm A during a clinical outbreak of VHS. Mussels $(\mathrm{n}=200)$ collected from Farm $\mathrm{C}$ were divided into 2 groups of 100 mussels each (Group I and Group II) and placed arbitrarily into 2 different aerated tubs each filled with $10 \mathrm{l}$ of seawater from Farm A. The tubs were kept in a refrigerated dark room at $8^{\circ} \mathrm{C}$. Four rainbow trout of approximately $1 \mathrm{~kg}$ each, with symptoms typical of acute septic infection, i.e. dark skin colour and exophthalmia, were collected from the farm and transferred into the tubs, 2 fish in each. The first 2 fish were held together with Group I for 10 min and the other 2 fish were kept with Group II for $20 \mathrm{~min}$. Due to ethical issues, the diseased rainbow trout were kept in the tubs for as little time as possible. To determine whether the fish used for the infection trial were infected by VHSV, the fish were euthanized and necropsied immediately after the end of exposure. Samples from the spleen, anterior kidney and heart were examined individually by cell culture and ELISA for fish viruses according to Commission Decision 2001/183/EC (EC 2001). After the fish were removed, the exposure of the mussels to the water, now presumably contaminated with VHSV, continued for an additional $4 \mathrm{~h}$. The water temperature in the tub was $5^{\circ} \mathrm{C}$ at the beginning and $8^{\circ} \mathrm{C}$ at the end of the exposure. The mussels started to filter water a few minutes post transfer. At the end of the exposure, the mussels were still alive, as they reacted to physical contact by closing their shells.
Table 3. Viral haemorrhagic septicaemia virus (VHSV) isolations and realtime reverse transcriptase polymerase chain reaction (qRT-PCR) results from 2 bath challenges of blue mussels with VHSV grown in cell culture and VHSV from infected rainbow trout. In both trials, Aquarium I and II are test aquariums and Aquarium III is a negative control aquarium in which all results were negative and are not shown in the table. N: number; nd: not done; $\mathrm{CI}$ : confidence interval

\begin{tabular}{|c|c|c|c|c|}
\hline \multirow{3}{*}{ Time of sampling } & \multirow[t]{3}{*}{ Aquarium } & \multicolumn{3}{|c|}{ N samples positive / N samples tested } \\
\hline & & \multicolumn{2}{|c|}{ Mussel hepatopancreas } & \multirow{2}{*}{$\begin{array}{l}\text { Aquarium } \\
\text { water } \\
\text { qRT-PCR }\end{array}$} \\
\hline & & $\begin{array}{l}\text { Virus isolation } \\
\text { in cell culture }\end{array}$ & qRT-PCR & \\
\hline \multicolumn{5}{|l|}{ Bath challenge with VHSV } \\
\hline 0 (before challenge) & I, II, III & $0 / 5$ & nd & nd \\
\hline $6 \mathrm{~h}$ (at end of challenge) & I & $5 / 5$ & $5 / 5$ & nd \\
\hline $1 \mathrm{~d}$ & I & $0 / 5$ & $3 / 5$ & nd \\
\hline $1 \mathrm{~d}$ (at end of challenge) & II & $0 / 5$ & $4 / 5$ & nd \\
\hline $2 \mathrm{~d}$ & I & $0 / 5$ & $1 / 5$ & nd \\
\hline $2 \mathrm{~d}$ & II & $0 / 5$ & $2 / 5$ & nd \\
\hline $3 \mathrm{~d}$ & I & $0 / 5$ & $0 / 5$ & nd \\
\hline $3 \mathrm{~d}$ & II & $0 / 5$ & $4 / 5$ & nd \\
\hline $6 \mathrm{~d}$ & I & $0 / 5$ & $3 / 5$ & nd \\
\hline $6 \mathrm{~d}$ & II & $0 / 5$ & $2 / 5$ & nd \\
\hline Total (N, \%, $95 \%$ CI) & & $\begin{array}{c}5 / 50 \\
(10,4-21)\end{array}$ & $\begin{array}{c}24 / 45 \\
(53,39-67)\end{array}$ & \\
\hline \multicolumn{5}{|c|}{ Bath challenge with VHSV-infected rainbow trout } \\
\hline 0 (before challenge) & I, II, III & $0 / 3$ & $0 / 3$ & $0 / 1$ \\
\hline At end of 10 min challenge & e I & $0 / 2$ & $2 / 2$ & $2 / 2$ \\
\hline At end of $20 \mathrm{~min}$ challenge & II & $0 / 2$ & $1 / 2$ & $2 / 2$ \\
\hline \multirow[t]{2}{*}{$1 \mathrm{~d}$} & I & $0 / 2$ & $1 / 2$ & $1^{\mathrm{a} / 1}$ \\
\hline & II & $0 / 2$ & $1^{\mathrm{a} / 2}$ & $1^{\mathrm{a} / 1}$ \\
\hline \multirow[t]{2}{*}{$2 \mathrm{~d}$} & I & $0 / 2$ & $2 / 2$ & $1^{\mathrm{a} / 1}$ \\
\hline & II & $0 / 2$ & $0 / 2$ & $1^{\mathrm{a} / 1}$ \\
\hline \multirow[t]{2}{*}{$3 \mathrm{~d}$} & I & $0 / 2$ & $1 / 2$ & $0 / 1$ \\
\hline & II & $0 / 2$ & $0 / 2$ & $0 / 1$ \\
\hline \multirow[t]{2}{*}{$4 \mathrm{~d}$} & I & $0 / 2$ & $0 / 2$ & $0 / 1$ \\
\hline & II & $0 / 2$ & $0 / 2$ & $0 / 1$ \\
\hline \multirow[t]{2}{*}{$6 \mathrm{~d}$} & I & $0 / 2$ & $1^{\mathrm{a} / 2}$ & $0 / 1$ \\
\hline & II & $0 / 2$ & $1^{\mathrm{a} / 2}$ & $0 / 1$ \\
\hline \multirow[t]{2}{*}{$8 \mathrm{~d}$} & I & $0 / 2$ & $0 / 2$ & $0 / 1$ \\
\hline & II & $0 / 2$ & $0 / 2$ & $0 / 1$ \\
\hline \multirow[t]{2}{*}{$11 \mathrm{~d}$} & I & $0 / 2$ & $0 / 2$ & $0 / 1$ \\
\hline & II & $0 / 2$ & $0 / 2$ & $0 / 1$ \\
\hline \multirow[t]{2}{*}{$14 \mathrm{~d}$} & I & $0 / 2$ & $0 / 2$ & $0 / 1$ \\
\hline & II & $0 / 2$ & $0 / 2$ & $0 / 1$ \\
\hline \multirow[t]{2}{*}{$22 \mathrm{~d}$} & I & $0 / 2$ & $1^{\mathrm{a}} / 2$ & $0 / 1$ \\
\hline & II & $0 / 2$ & $0 / 2$ & $0 / 1$ \\
\hline \multirow[t]{2}{*}{$27 \mathrm{~d}$} & I & $0 / 2$ & $0 / 2$ & $0 / 1$ \\
\hline & II & $0 / 2$ & $0 / 2$ & $0 / 1$ \\
\hline \multirow[t]{2}{*}{$29 \mathrm{~d}$} & I & $0 / 2$ & $1^{\mathrm{a} / 2}$ & $0 / 1$ \\
\hline & II & $0 / 2$ & $0 / 2$ & $0 / 1$ \\
\hline Total $(\mathrm{N}, \%, 95 \% \mathrm{CI})$ & & $\begin{array}{c}0 / 51 \\
(0,0-7)\end{array}$ & $\begin{array}{c}7 / 51 \\
(14,7-26)\end{array}$ & $\begin{array}{c}4 / 27 \\
(15,6-32)\end{array}$ \\
\hline
\end{tabular}


Aquarium I and Aquarium II) the day after exposure. The aquarium water that was used for the infection trial was transported from control Farm C. One aquarium with 100 mussels from Farm C was prepared as the control (Aquarium III). Five filtering mussels from each aquarium and 11 of aquarium water were collected before the water was changed and examined for the presence of VHSV on Days 1-4, 6, 8, 11, 14, 22, 27 and 29 (Table 3). The treatment of the aquariums and the facilities to avoid viral contamination was the same as that described for the first bath challenge.

\subsection{Examination of samples from mussels, seawater and liquid waste for VHSV by virus isolation}

The samples from seawater, liquid waste and hepatopancreas were processed according to standard virological procedures. The hepatopancreas of a maximum of 5 mussels was pooled in 9 volumes of MEM, homogenized and centrifuged at $4000 \times g$ $\left(20 \mathrm{~min}\right.$ at $\left.4^{\circ} \mathrm{C}\right)$. The seawater and liquid waste samples were diluted similarly but not homogenized. All samples were kept on ice during the process. Supernatants from the organ homogenate, diluted water samples and liquid waste were collected, and $150 \mu \mathrm{l}$ were inoculated into 24-well tissue culture plates with monolayers of 2 different cell lines: bluegill fry fibroblast BF-2 cells (Wolf et al. 1966) and epithelioma papulosum cyprinid cells (Fijan et al. 1983, Olesen \& Vestergård Jørgensen 1992). The remaining supernatant was frozen to $-80^{\circ} \mathrm{C}$ for later examination using qRT-PCR. The inoculated cells were cultivated for 2 consecutive passages for a total of $14 \mathrm{~d}$. Cell cultures with cytopathic effects were collected and frozen for later confirmation of the presence of VHSV using qRTPCR (Vennerström et al. 2017). Due to technical problems, virus isolation was not performed from seawater and liquid waste samples taken in April and May 2008.

\subsection{Treatment of samples from seawater, aquarium water, liquid waste and sediment}

Water samples were treated with methods described by Maunula et al. (2012) with some modifications. In general, 51 of the seawater samples were prefiltered through a Waterra ${ }^{\circledR}$ filter (FHT700) (Powell et al. 2000), but in some cases, only 1 or 31 could pass through the filter. Filtering was continued through a GF/F membrane (Whatman
International). Virus particles were eluted from the Waterra filter using $50 \mathrm{ml}$ of $50 \mathrm{mM}$ glycine-3\% beef extract ( $\mathrm{pH}$ 9.5) and from the GF/F membrane with $1 \mathrm{ml}$ AVL lysis buffer (Qiagen) after shaking for $10 \mathrm{~min}$ at room temperature. Both eluates were subjected to RNA extraction with a Viral RNA Mini Kit (Qiagen). Aquarium water from the infection trials and the liquid waste samples were not filtered. For determining the presence of VHSV, $140 \mu \mathrm{l}$ of each sample were collected for RNA extraction with a Qiagen Viral RNA Mini Kit. Sediment samples were diluted by taking $5 \mathrm{~g}$ of each sample and adding $1 \mathrm{ml}$ of phosphate-buffered saline. Suspensions were briefly stirred, and $200 \mu$ of the liquid were taken for RNA extraction, which was performed using a Nuclisens magnetic extraction kit (Biomérieux). RNA was analysed using qRT-PCR both undiluted and in 1:10 dilution (RNase-free water).

\section{6. $q R T-P C R$}

The supernatants from the hepatopancreas-MEM suspension that was prepared for virus isolation, supernatants from the cell culture showing a cytopathic effect and the sediment and water samples were examined for the presence of VHSV using a qRT-PCR method published earlier by Vennerström et al. (2017). The qRT-PCR method was compared to virus isolation in cell culture and correlated well with the virus isolation results (kappa value $=0.877$, sensitivity =1, specificity = 0.959; Vennerström et al. 2017). Briefly, qRT-PCR was performed with a QuantiTect Probe RT-PCR Kit (Qiagen) according to the manufacturer's instructions. The primers and the probe (MedProbe) for the qRT-PCR were designed according to the VHSV nucleocapsid gene sequence from GenBank, accession no. D00687, after Chico et al. (2006) (Table 3). A threshold cycle $\left(C_{t}\right)$ cut-off of 36 $(<30$ copies) was used in the analysis as estimated in our earlier study (Vennerström et al. 2017). However, results with $\mathrm{C}_{\mathrm{t}}>36$ (showing a sigmoidal amplification curve) are considered as possible traces of VHSV RNA. The amplification efficiency of the qPCR reaction of a standard curve based on the slope $(-3.44)$ was $96.8 \%$.

\subsection{Statistical analyses}

Due to small numbers of samples, data were only described. We used $95 \%$ confidence intervals (CI) for comparison of percentages. They were calculated 
using Epitools (Sergeant 2019) with the Wilson method (Brown et al. 2001).

\section{RESULTS}

\subsection{Occurrence of VHSV in environmental samples from fish farms and a processing plant}

The sampling scheme, methods and results from the testing of samples for VHSV are presented in Table 1.

\subsubsection{Seawater}

Only 1 sample taken from seawater at Farm A in April $2008\left(4^{\circ} \mathrm{C}\right)$ gave a weak positive reaction $(95 \%$ CI: 0.8-23) when tested for VHSV RNA using qRTPCR (Table 1). All seawater samples collected in May $2008\left(4-10^{\circ} \mathrm{C}\right)$ from Farm B were negative $(95 \% \mathrm{CI}$ : 0-17) for VHSV RNA. Virus isolation was not performed from any samples taken in April and May 2008. All samples that were collected in January and March $2009\left(0-2^{\circ} \mathrm{C}\right)$ were positive (95\% CI: 30-95) for VHSV RNA using qRT-PCR after filtering, but no virus could be isolated from the same samples. No difference was noticed between the samples taken from the surface or from $2 \mathrm{~m}$ depth.

\subsubsection{Sediment from the sea bed}

All collected samples from the sediment beneath the fish farms were negative (95\% CI: 0-28) for VHSV RNA using qRT-PCR.

\subsubsection{Liquid waste}

All liquid waste samples taken in January 2009 $\left(2{ }^{\circ} \mathrm{C}\right)$ from the processing plant before liquid waste disinfection were positive for VHSV RNA using qRTPCR (95\% CI: 74-100), and $73 \%$ of the samples tested by cell culture (95\% CI: 43-90) were positive for VHSV (Table 1). No virus could be detected by either method in samples taken after final disinfection of the liquid waste. In March $2009\left(0^{\circ} \mathrm{C}\right)$ at the second sampling time, when only whitefish were processed, $50 \%$ of the samples tested positive using qRT-PCR (95\% CI: 15-85), and VHSV was isolated from $63 \%$ of the samples (95\% CI: 31-86). The liquid waste disinfection system was not running at the time of the second sampling, and therefore disinfected effluent could not be collected for testing.

\subsection{Occurrence of VHSV in wild mussels}

VHSV was not isolated from the 62 pools of 193 blue mussels collected from fish farms (Table 2) that were tested (95\% CI: 0-6). Altogether, 50 pools of organ samples from blue mussels were tested using qRT-PCR and were found to be negative (95\% CI: 0-7) for VHSV RNA, except in May 2006, when 1 sample from Farm A gave a weak signal $\left(C_{t}>36\right)$.

\subsection{Infection trials with blue mussels}

\subsubsection{Bath challenge of blue mussels with VHSV}

All tests from mussel samples taken before the challenge started and from control Aquarium III were negative (Table 3). VHSV was isolated only once in this bath challenge performed with VHSV. The isolation was made from the hepatopancreas at the end of a $6 \mathrm{~h}$ challenge in Aquarium I (Table 3). No virus was isolated from Aquarium II mussels (1 d challenge) on any occasion. However, qRT-PCR gave positive signals for VHSV RNA in both Aquariums I and II throughout the follow-up period of $6 \mathrm{~d}$.

\subsubsection{Bath challenge of blue mussels with VHSV-infected rainbow trout}

The 4 rainbow trout used to challenge mussels in the infection trial showed typical signs of a septic infection at necropsy: dark skin colour, exophthalmia, reddish fluid in the abdominal cavity and petechiae in the skin, visceral adipose tissue, liver and muscle tissue. VHSV was isolated from all 4 individually tested rainbow trout when analysed after the challenge. Genotype was not determined, but VHSV genotype Id had been isolated from the same fish population 3 d earlier (Vennerström et al. 2017). Hepatopancreas samples of the blue mussels in both Aquarium I and II were VHSV negative in the cell culture throughout the follow-up period of $29 \mathrm{~d}$ (Table 3). qRT-PCR gave clearly positive results in Aquarium I up to $3 \mathrm{~d}$ post infection and in Aquarium II at the end of the 20 min challenge. In addition, traces of viral RNA $\left(C_{t}>36\right)$ were detected several times in the mussels throughout the follow-up period until Day 29 in Aquarium I and Day 6 in Aquarium II. In contrast, water samples that were analysed for VHSV RNA showed a weak signal for only $2 \mathrm{~d}$ in both groups. All samples from the control (Aquarium III) were negative by cell culture and qRT-PCR. 


\section{DISCUSSION}

We found that in seawater close to the net pens with VHS diseased rainbow trout populations and next to loading docks of processing plants handling VHSV-positive fish, VHSV was more frequently detected at cold water temperatures during wintertime than in spring. Water temperature in the study area was close to $0^{\circ} \mathrm{C}$ in January-March and $4-10^{\circ} \mathrm{C}$ in April-May. Daylight is only $6 \mathrm{~h}$ in January but increases to 14-16 h in April-May (Nordlund 2008, Cornwall et al. 2020). The low amount of UV radiation in wintertime (Finnish Meteorological Institute 2019) in the study area together with short daylight hours and cold water temperature seems to be favourable for virus survival. The result is consistent with previous studies where VHSV was reported to be sensitive to UV light and survive longer in cold water temperatures than in warm (Ahne 1982, Parry \& Dixon 1997, Øye \& Rimstad 2001, Yoshimizu et al. 2005, Hawley \& Garver 2008, Afonso et al. 2012).

The difference in temperature between winter and spring was not so high that temperature could be considered of high importance alone. According to the literature, there are indications that virus survival could be decreased in an environment with bacteriaand virus-inhibiting compounds (Mori et al. 2002, Bovo et al. 2005). Extremely low water temperatures could have a negative impact on the number of bacteria-, algae- and virus-inhibiting compounds in the water and therefore give VHSV more favourable conditions than in warmer water.

Liquid waste samples from the processing plant collected in March 2009 were positive for VHSV RNA, although only clinically healthy whitefish had been processed at the time. Whitefish were not sampled in this study, but in previous studies, we noticed that although whitefish are not easily infected with VHSV genotype Id, some fish in the population may get infected and virus replication occurs (Vennerström et al. 2018). The processed whitefish were farmed next to the processing plant where VHSVpositive rainbow trout had been processed earlier the same year. It is possible that whitefish may have been infected by VHSV from that processing plant. Another possibility for this virus-positive finding is that the processing line was highly contaminated by VHSV RNA from infected rainbow trout processed earlier. According to our study, it is possible that processing plants handling VHSV-positive fish and the surrounding environment are contaminated with the virus, especially in winter. For this reason, any contact between processing plants and farmed suscepti- ble fish populations should be avoided, especially during the coldest and darkest time of the year. This statement is also supported by a study conducted by Oidtmann et al. (2011), who found high amounts of VHSV Ia in both sub-clinically affected and survivors of a VHSV-infected rainbow trout population. They also suggested that processed fish from an infected population and effluent from the processing plant could pose a significant risk for spreading virus.

Based on the results of our studies on blue mussels, it can be assumed that VHSV is not able to replicate in blue mussels. This was shown by taking samples from the hepatopancreas of mussels living in VHSVinfected fish farms and by 2 different infection trials with VHSV. The challenges were performed with 2 different methods, but the result was the same regardless of the method used. In our challenge studies, VHSV RNA was detected in aquarium water only during the bath challenge, but somewhat longer in the samples taken from mussels. This difference could have been due to the frequent water changes in the test aquariums in order to give the mussels as good conditions in the aquarium as possible. The finding of viral RNA in mussels could also indicate that they may serve as a physical attachment surface for VHSV, protecting the virus from environmental effects by providing a cleaner environment. VHSV is an enveloped virus that is not as resistant to environmental effects as birnaviruses, e.g. IPNV, that are nonenveloped and have been found in free-living molluscs (Mortensen et al. 1992, Rivas et al. 1993, Bovo et al. 2005). Molloy et al. (2013) showed that IPNV could be transferred by blue mussels to Atlantic salmon Salmo salar.

Sampling of blue mussels for conducting virology is demanding, as it is practically impossible to obtain samples without contaminating them with virus that could exist in the water in which they are living. It is also not possible to disinfect the inside of the shell without contaminating the internal organs with disinfectants that would interfere with virus isolation and give false negative results. We found parallel sampling of both hepatopancreas of challenged mussels and their aquarium water to be quite reliable in testing the role of blue mussels in preserving VHSV.

Replication of VHSV in mussels was unlikely, since if increased secretion of the virus had occurred in the mussels, one would expect the virus load in the aquarium water to increase as well. The unlikely role of blue mussels being carriers of VHSV in our study could also explain why VHS was successfully eradicated in 2 similar farming sites for rainbow trout on the west and south coast of Finland (Raja-Halli et al. 
2006). These farms also had high densities of blue mussels in their environment. If the VHSV could replicate in mussel tissues, one would expect those eradications to have failed.

\section{CONCLUSIONS}

Processing plants handling VHSV-positive fish and seawater close to VHSV-positive fish populations are likely contaminated with VHSV during wintertime when daylight is sparse and temperatures are close to $0^{\circ} \mathrm{C}$. Contact with contaminated facilities increases the risk of the disease spreading to susceptible fish populations. Based on our results, blue mussels may not be a relevant source of VHSV, as the virus was not shown to replicate in mussel tissues, but they could provide VHSV a physical protective environment that could prolong the survival time of the virus, although probably not for more than a few days.

Acknowledgements. This work was funded by the Finnish Ministry of Agriculture and Forestry, Dno 4876/501/2005, project 310159. We thank Suvi Kapiainen for technical assistance in the laboratory and Tapani Lyytikäinen and Riikka Holopainen for critical reading of the manuscript.

\section{LITERATURE CITED}

Afonso LOB, Richmond Z, Eaves AA, Richard J, Hawley LM, Garver KA (2012) Use of ultraviolet C (UVC) radiation to inactivate infectious hematopoietic necrosis virus (IHNV) and viral hemorrhagic septicemia virus (VHSV) in fish processing plant effluent. J Aquac Res Dev 3:120

Ahne W (1982) Comparative studies on the stability of four fish-pathogenic viruses (VHSV, PFR, SVCV, IPNV). Zentralbl Veterinärmed B 29:457-476

* Ammayappan A, Vakharia VN (2009) Molecular characterization of the Great Lakes viral hemorrhagic septicemia virus (VHSV) isolate from USA. Virol J 6:171

Bain MB, Cornwell ER, Hope KM, Eckerlin GE and others (2010) Distribution of an invasive aquatic pathogen (viral hemorrhagic septicemia virus) in the Great Lakes and its relationship to shipping. PLOS ONE 5:e10156

Bovo G, Hill B, Husby A, Håstein T and others (2005) Fish egg trade work package 3 report: Pathogen survival outside the host, and susceptibility to disinfection. VESO, Oslo. https://pdfs.semanticscholar.org/c396/ ed2286949bfedd94842ee23f018a81ee9ade.pdf

* Brown LD, Cai TT, DasGupta A (2001) Interval estimation for a binomial proportion. Stat Sci 16:101-133

* Chico V, Gomez N, Estepa A, Perez L (2006) Rapid detection and quantitation of viral hemorrhagic septicemia virus in experimentally challenged rainbow trout by real-time RT-PCR. J Virol Methods 132:154-159

Cornwall C, Horiuchi A, Lehman C (2020) NOAA Earth System Research Laboratory, Solar calculator. www. esrl.noaa.gov/gmd/grad/solcalc/sunrise.html (accessed 26 Feb 2020)
EC (European Commission) (2001) 2001/183/EC(2001): Commission Decision of 22 February 2001 laying down the sampling plans and diagnostic methods for the detection and confirmation of certain fish diseases and repealing Decision 92/532/EEC. https://eur-lex.europa. eu/legal-content/EN/TXT/?uri=CELEX\%3A32001D0183 (accessed 26 Feb 2020)

Einer-Jensen K, Ahrens P, Forsberg R, Lorenzen N (2004) Evolution of the fish rhabdovirus viral haemorrhagic septicaemia virus. J Gen Virol 85:1167-1179

Einer-Jensen K, Ahrens P, Lorenzen N (2005) Parallel phylogenetic analyses using the N, G or Nv gene from a fixed group of VHSV isolates reveal the same overall genetic typing. Dis Aquat Org 67:39-45

Elsayed E, Faisal M, Thomas M, Whelan G, Batts W, Winton $J(2006)$ Isolation of viral haemorrhagic septicaemia virus from muskellunge, Esox masquinongy (Mitchill), in Lake St Clair, Michigan, USA reveals a new sublineage of the North American genotype. J Fish Dis 29:611-619

Fijan N, Sulimanović D, Bearzotti M, Muzinić D and others (1983) Some properties of the Epithelioma papulosum cyprini (EPC) cell line from carp Cyprinus carpio. Ann Inst Pasteur Virol 134:207-220

Finnish Meteorological Institute (2019) UV daily dose composites. http://sampo.fmi.fi/dose_comp.html

*Hawley LM, Garver KA (2008) Stability of viral hemorrhagic septicemia virus (VHSV) in freshwater and seawater at various temperatures. Dis Aquat Org 82:171-178

*Hervé-Claude LP, Carpenter TE, Hedrick RP (2008) Risk of introducing viral hemorrhagic septicemia virus (VHSV) to the Chilean South Pacific via sardine imports from Europe. Dis Aquat Org 78:199-207

Kingsley DH, Richards GP (2003) Persistence of hepatitis A virus in oysters. J Food Prot 66:331-334

* Maunula L, Söderberg K, Vahtera H, Vuorilehto VP and others (2012) Presence of human noro- and adenoviruses in river and treated waste water, a longitudinal study and method comparison. J Water Health 10:87-99

Molloy SD, Pietrak MR, Bricknell I, Bouchard DA (2013) Experimental transmission of infectious pancreatic necrosis virus from the blue mussel, Mytilus edulis, to cohabitating Atlantic salmon (Salmo salar) smolts. Appl Environ Microbiol 79:5882-5890

* Molloy SD, Pietrak MR, Bouchard DA, Bricknell I (2014) The interaction of infectious anaemia virus (ISAV) with blue mussel, Mytilus edulis. Aquac Res 45:509-518

Mori KI, Iida $H$, Nishizawa $T$, Arimoto $M$, Nakajima $K$, Muroga K (2002) Properties of viral hemorrhagic septicemia virus (VHSV) isolated from Japanese flounder Paralichtus olivaceus. Fish Pathol 37:169-174

Mortensen SH, Bachere E, Le Gall G, Mailhe E (1992) Persistence of infectious pancreatic necrosis virus (IPNV) in scallops Pecten maximus. Dis Aquat Org 12: 221-227

Nordlund A (2008) Finland's weather and light. A meteorologically minded guide to the four seasons of Finland. https://finland.fi/life-society/finlands-weather-and-light/ (accessed 27 Feb 2020)

Oidtmann B, Joiner C, Stone D, Dodge M, Reese RA, Dixon P (2011) Viral load of various tissues of rainbow trout challenged with viral haemorrhagic septicaemia virus at various stages of disease. Dis Aquat Org 93:93-104

Oidtmann B, Dixon P, Way K, Joiner C, Bayley AE (2018) Risk of waterborne virus spread - review of survival of relevant fish and crustacean viruses in the aquatic envi- 
ronment and implications for control measures. Rev Aquacult 10:641-669

Olesen NJ, Vestergård Jørgensen PE (1992) Comparative susceptibility of three fish cell lines to Egtved virus, the virus of viral haemorrhagic septicaemia (VHS). Dis Aquat Org 12:235-237

Øye AK, Rimstad E (2001) Inactivation of infectious salmon anaemia virus, viral haemorrhagic septicaemia virus and infectious pancreatic necrosis virus in water using UVC irradiation. Dis Aquat Org 48:1-5

Parry L, Dixon PF (1997) Stability of nine viral haemorrhagic septicaemia virus (VHSV) isolates in seawater. Bull Eur Assoc Fish Pathol 17:31-36

* Pearce FM, Oidtmann BC, Thrush MA, Dixon PF, Peeler EJ (2014) Do imports of rainbow trout carcasses risk introducing viral haemorrhagic septicaemia virus into England and Wales? Transbound Emerg Dis 61:247-257

* Phelps NBD, Patnayak DP, Jiang Y, Goyal SM (2012) The use of a one-step real-time reverse transcription polymerase chain reaction (rRT-PCR) for the surveillance of viral hemorrhagic septicemia virus (VHSV) in Minnesota. J Aquat Animal Health 24:238-243

* Pierce LR, Stepien CA (2012) Evolution and biogeography of an emerging quasispecies: diversity patterns of the fish Viral Hemorrhagic Septicemia virus (VHSv). Mol Phylogenet Evol 63:327-341

Powell, KL, Tellam, JH, Barrett, MH, Pedley S, Stagg K, Greswell RB, Rivett MO (2000) Optimisation of a new method for detection of viruses in groundwater. Report to the UK Environment Agency, National Groundwater and Contaminated Land Centre Project NC/99/40

* Power UF, Collins JK (1989) Differential depuration of poliovirus, Escherichia coli, and a coliphage by the common mussel, Mytilus edulis. Appl Environ Microbiol 55: 1386-1390

* Raja-Halli M, Vehmas TK, Rimaila-Pärnänen E, Sainmaa S, Skall HF, Olesen NJ, Tapiovaara H (2006) Viral haemorrhagic septicaemia (VHS) outbreaks in Finnish rainbow trout farms. Dis Aquat Org 72:201-211

* Richards GP (1985) Outbreaks of shellfish-associated enteric virus illness in the United States: requisite for development of viral guidelines. J Food Prot 48:815-823

Richards GP (1988) Microbial purification of shellfish: a review of depuration and relaying. J Food Prot 51: 218-251

Editorial responsibility: Lori Gustafson,

Fort Collins, Colorado, USA
Rivas C, Cepeda C, Dopazo CP, Novoa B, Noya M, Barja JL (1993) Marine environment as reservoir of birnaviruses from poikilothermic animals. Aquaculture 115: 183-194

Sergeant E (2019) Epitools epidemiological calculators. AusVet Animal Health Services and Australian Biosecurity Cooperative Research Centre for Emerging Infectious Disease. http://epitools.ausvet.com.au

Skår CK, Mortensen S (2007) Fate of infectious salmon anaemia virus (ISAV) in experimentally challenged blue mussels Mytilus edulis. Dis Aquat Org 74:1-6

Snow M, Cunningham CO, Melvin WT, Kurath G (1999) Analysis of the nucleoprotein gene identifies distinct lineages of viral haemorrhagic septicaemia virus within the European marine environment. Virus Res 63:35-44

V Vennerström P, Välimäki E, Lyytikäinen T, Hautaniemi M, Vidgren G, Koski P, Virtala AM (2017) Viral haemorrhagic septicaemia virus (VHSV Id) infections are detected more consistently using syndromic vs. active surveillance. Dis Aquat Org 126:111-123

Vennerström P, Välimäki E, Hautaniemi M, Lyytikäinen T, Kapiainen S, Vidgren G, Virtala AM (2018) Wild fish are negligible transmitters of viral haemorrhagic septicaemia virus (VHSV) genotype Id in the VHS restriction zone in Finland. Dis Aquat Org 131: 187-197

VHSV Expert Panel and Working Group (2010) Viral hemorrhagic septicemia virus (VHSV IVb) risk factors and association measures derived by expert panel. Prev Vet Med 94:128-139

Walker PJ, Benmansour A, Dietzgen R, Fang RX and others (2000) Family Rhabdoviridae. In: ICTV, Van Regenmortel MHV, Fauquet CM, Bishop DHL (eds) Virus taxonomy. Classification and nomenclature of viruses. Seventh report of the International Committee on Taxonomy of Viruses. Academic Press, New York, NY, p 562-583

Wolf K (1988) Fish viruses and fish viral diseases. Cornell University Press, Ithaca, NY

*Wolf K, Gravell M, Malsberger RG (1966) Lymphocystis virus: isolation and propagation in centrarchid fish cell lines. Science 151:1004-1005

Yoshimizu M, Yoshinaka T, Hatori S, Kasai H (2005) Survivability of fish pathogenic viruses in environmental water, and inactivation of fish viruses. Bull Fish Res Agency Suppl 2:47-54

Submitted: April 18, 2019; Accepted: January 27, 2020 Proofs received from author(s): February 27, 2020 